\title{
Effects of Elevated Sea Levels and Waves on Southern California Estuaries During the 2015-2016 El Niño
}

\author{
Madeleine E. Harvey ${ }^{1}$ (1) - Sarah N. Giddings ${ }^{1} \cdot$ Eric D. Stein $^{2} \cdot$ Jeffrey A. Crooks ${ }^{1,3} \cdot$ Christine Whitcraft $^{4} \cdot$ Timu Gallien $^{5}$. \\ John L. Largier ${ }^{6}$. Liesl Tiefenthaler ${ }^{2} \cdot$ Hallee Meltzer ${ }^{7} \cdot$ Geno Pawlak $^{8} \cdot$ Karen Thorne $^{9} \cdot$ Karina Johnston $^{10}$. \\ Richard Ambrose ${ }^{11} \cdot$ Stephen C. Schroeter ${ }^{12} \cdot$ Henry M. Page ${ }^{12} \cdot$ Hany Elwany ${ }^{13}$
}

Received: 24 August 2018 / Revised: 12 November 2019 / Accepted: 10 December 2019 / Published online: 16 January 2020

(C) The Author(s) 2020

\begin{abstract}
The 2015-2016 El Niño provided insight into how low-inflow estuaries might respond to future climate regimes, including high sea levels and more intense waves. High waves and water levels coupled with low rainfall along the Southern California coastline provided the opportunity to examine how extreme ocean forcing impacts estuaries independently from fluvial events. From November 2015 to April 2016, water levels were measured in 13 Southern California estuaries, including both intermittently closed and perennially open estuaries with varying watershed size, urban development, and management practices. Elevated ocean water levels caused raised water levels and prolonged inundation in all of the estuaries studied. Water levels inside perennially open estuaries mirrored ocean water levels, while those inside intermittently closed estuaries (ICEs) exhibited enhanced higher-high water levels during large waves, and tides were truncated at low tides due to a wave-built sand sill at the mouth, resulting in elevated detided water levels. ICEs closed when sufficient wave-driven sand accretion formed a barrier berm across the mouth separating the estuary from the ocean, the height of which can be estimated using estuarine lower-low water levels. During the 2015-2016 El Niño, a greater number of Southern California ICEs closed than during a typical year and ICEs that close annually experienced longer than normal closures. Overall, sill accretion and wave exposure were important contributing factors to individual estuarine response to ocean conditions. Understanding how estuaries respond to increased sea levels and waves and the factors that influence closures will help managers develop appropriate adaptation strategies.
\end{abstract}

Keywords El Niño $\cdot$ Estuaries $\cdot$ Water Levels $\cdot$ Intermittently closed estuaries

Communicated by John C. Callaway

Electronic supplementary material The online version of this article (https://doi.org/10.1007/s12237-019-00676-1) contains supplementary material, which is available to authorized users.

Madeleine E. Harvey

meharvey@ucsd.edu

1 Scripps Institution of Oceanography, University of California San Diego, 9500 Gilman Dr, La Jolla, CA 92093-0206, USA

2 Southern California Coastal Water Research Project, 3535 Harbor Blvd., Suite 110, Costa Mesa, CA 92626, USA

3 Tijuana River National Estuarine Research Reserve, 301 Caspian Way, Imperial Beach, CA 91932, USA

4 Biological Sciences, California State University Long Beach, 1250 Bellflower Blvd., Long Beach, CA 90840-9502, USA

5 Civil and Environmental Engineering, University of California Los Angeles, 420 Westwood Plaza, Los Angeles, CA 90095, USA

6 Coastal \& Marine Sciences Institute, University of California Davis, Bodega Bay, CA 94923, USA
7 Florida Center for Environmental Studies, Florida Atlantic University, 3200 College Ave., Davie, FL 33314, USA

8 Mechanical and Aerospace Engineering, University of California San Diego, 9500 Gilman Dr., La Jolla, CA 92093-0206, USA

9 Western Ecological Research Center, United States Geological Survey, One Shields Avenue University of California, Davis, CA 95616, USA

10 The Bay Foundation, 8334 Lincoln Blvd. \#310, Los Angeles, CA 90045, USA

11 Institute of the Environment and Sustainability, University of California Los Angeles, 420 Westwood Plaza, Los Angeles, CA 90095, USA

12 Marine Science Institute University of California Santa Barbara, Santa Barbara, CA 93106, USA

13 Coastal Environments, 2166 Avenida De La Playa \#E, La Jolla, CA 92037, USA 


\section{Introduction}

Estuaries and associated wetlands provide extensive ecosystem functions and services, including biodiversity support, carbon sequestration, water quality improvement, and flooding abatement (Zedler and Kercher 2005; Takekawa et al. 2011; Holmquist et al. 2018). Under climate change, it is important to understand how such systems will respond and adapt. In particular, the balance between wetland resiliency to local sea-level rise and their role in mitigating the effects of sea-level rise is not well understood (Shepard et al. 2011). This is especially true in traditionally under-researched systems such as low-inflow estuaries. Low-inflow estuaries are found worldwide (e.g., Australia, South Africa, Portugal, Spain, Morocco, Chile, Mexico, and the USA; Largier 2010) and receive smaller and more episodic freshwater inputs than their "classical" counterparts found in wetter climates with larger watersheds (Largier et al. 1997; Ranasinghe and Pattiaratchi 2003; Behrens et al. 2013; Rich and Keller 2013; Williams and Stacey 2016).

In Southern California, all estuaries are low-inflow estuaries and are threatened by both continued urbanization and climate change. More than 100 estuaries line the highly urbanized Southern California coastline (Fig. 1 and Doughty et al. 2018), all with varying degrees of physical modifications, including the damming and channelizing of river inflows; the construction of breakwaters and jetties at inlets; the dredging of channels, inlets, and harbors; the construction of roads splitting systems; and the direct filling of wetlands (e.g., Pratt 2014; Los Peñasquitos Lagoon Foundation et al. 2016). Despite these threats, these systems are extremely important to the regional economy and ecology (Zedler and Kercher 2005; California Natural Resources Agency 2010).

In general, low-inflow estuaries along coasts with strong wave conditions are bar-built estuaries affected by the presence of a wave-built bar/sill, and subject to mouth closure. In barbuilt estuaries, low-tide water levels are typically perched above ocean water levels even when the mouth is open, due to hydraulic or frictional control exerted by the shallow sill found in the mouth or immediately landward (i.e., the flood tide shoal). Water drains slowly from the estuary until the ocean water level rises again above the sill elevation (e.g., Williams and Stacey 2016). While waves can transport and deposit sediment in the estuary mouth, strong tidal exchange and/or river discharge scours the inlet channel and exports sediment from the mouth. In estuaries with low or intermittent river outflow and/or small watersheds and tidal areas, wave-driven sediment accumulation can exceed tidal/fluvial erosion leading to the formation of a sill or barrier berm at the estuary mouth that separates the estuary from the ocean (e.g., Largier et al. 1992; Elwany et al. 1998; Morris and Turner 2010; Behrens et al. 2009; Behrens et al. 2013; Rich and Keller 2013; Orescanin and Scooler 2018). A common feature globally, estuaries that close intermittently have been referred to by many names (Tagliapietra et al. 2009), including intermittently closed and open lakes and lagoons (ICOLL, Roy et al. 2001), temporarily opening and closing estuaries (TOCE, Whitfield 1992), intermittently open estuaries (IOE, Jacobs et al. 2010), intermittently open/closed
Fig. 1 Observation locations. Southern California coastline with estuaries (circles), tide gauges (stars), weather stations (triangles), and wave buoys (squares). Estuaries included in this study are labeled and split into perennially open (large open circles) and intermittently closed (large filled circles). Wave roses are shown at each estuary entrance (blues) and at the offshore wave buoy (oranges). Estuary wave data were from MOP hindcast data (cdip.ucsd. edu, O'Reilly et al., 2016). Offshore data from CDIP San Nicholas Island observational buoy (cdip.ucsd.edu, Station ID 067). Colors indicate percent occurrence of waves at each station from November 1, 2015, to April 1, 2016, within each wave height and direction band

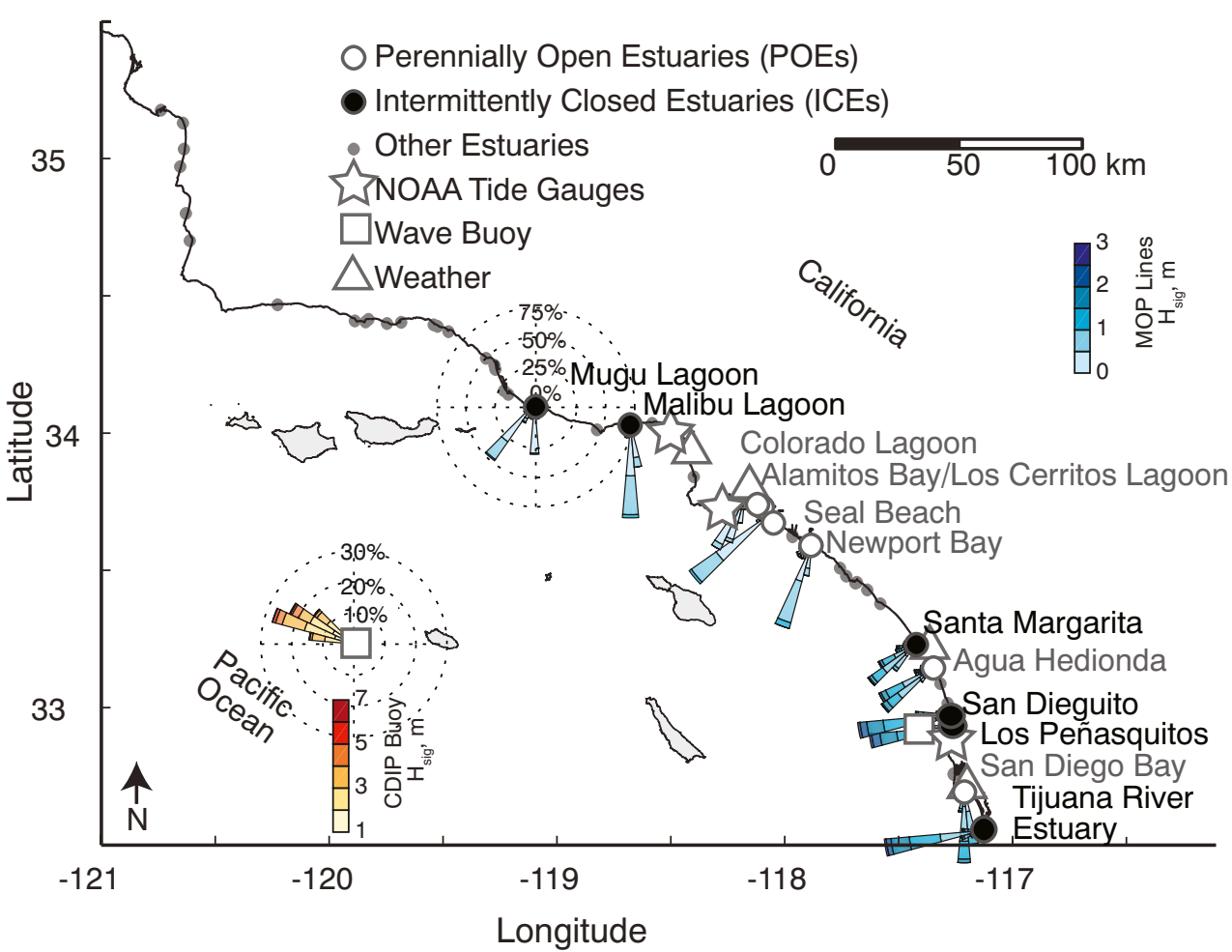


estuaries (IOCE, McSweeney et al. 2017), as well as intermittently closed estuaries (ICE, Williams and Stacey 2016), the last we use here, ICE.

In developed regions such as Southern California, many ICEs fail to re-open naturally due to adjacent beach nourishment (Ludka et al. 2018), reduced tidal prism, structurally impeded inlet migration, and altered fluvial inputs (Hastings and Elwany 2012). This results in environmental concerns, including flooding of low-lying development, undesirable water quality and impacts to fish and other marine organisms that require management attention (Largier et al. 2019). Many Southern California ICEs are managed to maintain an open state through dredging, building hard structures to prevent sedimentation and enhance scour, or some combination of methods that functionally convert these ICEs to perennially open estuaries (POEs). As communities and coastal managers develop plans for addressing sea-level rise and restoration programs (e.g., California Natural Resources Agency 2010; San Elijo Lagoon Conservancy and AECOM 2016; Los Peñasquitos Lagoon Foundation et al. 2016; Southern California Wetlands Recovery Project 2018; Largier et al. 2019), there remain several critical questions as to how these systems will respond to rising sea levels and a changing climate, including if marsh accretion rates will keep pace with sea level and how elevation and formation of barrier berms will change. Recent work has begun to address these questions (Zedler, 2010; Doughty et al. 2018; Thorne et al. 2018), but many issues such as future flooding and water quality depend on whether ICE closures will become more prevalent in the future and how communities and managers will respond.

The 2015-2016 El Niño provided an opportunity to assess how low-inflow estuaries might respond to climate change, as El Niño conditions mimic climate-change effects including sealevel rise and intensified wave events (e.g., Bromirski et al. 2003; Ludka et al. 2016; Barnard et al. 2017; Cayan et al. 2008; Cai et al. 2014). During the 2015-2016 winter, ocean water levels were persistently above average (Young et al. 2018) due to a combination of large-scale atmospheric forcing, thermal expansion effects, storm surge, and large wave events (e.g., Enfield and Allen 1980; Chelton and Davis 1982). The sea-level anomaly at the La Jolla tide gauge during the 20152016 El Niño was comparable to the amount of sea-level rise likely to occur by 2030 (National Research Council. 2012; Griggs et al. 2017), although other estimates suggest that these sea-level rise conditions may occur sooner (e.g., Sweet et al. 2017). Anomalously large waves recorded during the 2015-2016 winter along the Southern California coast (Flick 2016; Ludka et al. 2016; Barnard et al. 2017; Young et al. 2018) is consistent with prior El Niño events (Bromirski et al. 2003). Young et al. (2018) described that, although modeling suggests that storm tracks are projected to shift pole-ward resulting in decreased waves in sheltered regions of the Southern California Bight (e.g., Graham et al. 2013; Erikson et al. 2016), there is nonetheless likely to be an increase in extreme water level events due to rising seas alone in Southern California (Tebaldi et al. 2012; Sweet and Park 2014). At the same time as sea levels were high and wave events were more intense than normal, 2015-2016 winter precipitation was near or below average in Southern California (e.g., Lee et al. 2018; Siler et al. 2017). The combination of high ocean water levels, large waves, and low rainfall totals provided an opportunity to examine how climate-change-like anomalous ocean forcing impacts estuaries independently from fluvial events.

Previous work by Young et al. (2018) and Barnard et al. (2017) focused on how the anomalous 2015-2016 El Niño ocean water levels impacted coastal erosion. Young et al. (2018) specifically addressed morphology of cliffs, beaches, and estuary mouths; finding that estuary inlets accreted over the course of the winter, but they did not examine the effects on estuarine water levels. At the same time, Goodman et al. (2018) has reported on anomalous marsh flooding during the 2015-2016 El Niño without explaining how ocean forcing accounts for in-estuary conditions. Here, we use regional observations from the 2015-2016 El Niño in Southern California as an opportunity to address the effect of elevated sea level and large waves on low-inflow estuaries globally by identifying processes that link observed climate-change-like ocean conditions to in-estuary impacts.

We present data from 13 estuaries in Southern California in 2015-2016 to examine how anomalous ocean forcing (elevated sea level and extreme wave events) affects low-inflow estuaries. We compare the response of POEs and ICEs and examine the drivers of ICE closures. In addition to general hypotheses (e.g., water-level anomalies in estuaries simply track ocean water-level anomalies), we address hypotheses proposed by managers/scientists at management meetings, e.g., that the presence of a sill will affect estuarine water level responses to ocean forcing, and thus open ICEs will respond differently than POEs.

\section{Methods}

\section{Estuaries Studied}

Measurements were conducted in 13 estuaries (Fig. 1) of varying mouth morphology, size, marsh cover, and wave exposure along the Southern California Bight. Of these systems, six estuaries are classified as intermittently closed estuaries (ICEs): Mugu Lagoon, Malibu Lagoon, Santa Margarita Estuary, San Dieguito Lagoon, Los Peñasquitos Lagoon, and Tijuana River Estuary. Seven systems are classified as perennially open (POE). Six of those are open and/or exist as a result of mouth management including dredging and/or stabilization, Colorado Lagoon, Los Cerritos, Alamitos Bay, Seal Beach, Newport Bay, and Agua Hedionda, while one, San 
Diego Bay, is a naturally occurring POE (although managed through dredging and jetties). In our definition of ICE versus POE, it is important to note that most of the estuaries included here were ICEs prior to development; thus, here POE refers to estuaries whose mouths have been structurally altered (jetties, groins, revetments, etc.) to be perennially open. Some systems straddle these definitions, such as San Dieguito Lagoon where maintenance dredging in addition to engineered structures ensure the estuary remains open, in spite of significant sediment transport near its mouth and ongoing risk of closure. Nevertheless, because of large morphological changes at the mouth and the clear influence of a sill, we include San Dieguito Lagoon with ICEs. The estuaries in this study are relatively small systems (6-830 ha, Table 1) with the exception of San Diego Bay ( 5000 ha). Generally, ICEs have a higher percentage of marsh cover than POEs (Appendix).

\section{Representative Estuaries}

We chose to examine how estuarine water levels were influenced by ocean conditions in four select estuaries (2 ICEs and 2 POEs) before comparing the estuary types more broadly. Tijuana River Estuary (TRE) and Los Peñasquitos Lagoon (LPL) were chosen as representative ICEs, and Newport Bay (NB) and San Diego Bay (SDB) were chosen as representative POEs. The representative sites were chosen because they do not straddle the definition of mouth state and because they have the most complete data records. Water level data for SDB, TRE, and LPL are in absolute height relative to a fixed datum ("Water Level Data" section) and date back to 2005 enabling us to put the 2015-2016 winter season in a longterm context. In LPL, additional morphodynamic measurements allowed us to relate ICE water level measurements to inlet morphology changes.

\section{Data Collection Techniques}

\section{Water Level Data}

Coastal water level measurements (6-min interval) were extracted from the La Jolla, Los Angeles, and Santa Monica National Oceanic and Atmospheric Administration (NOAA) tide gauges (tidesandcurrents.noaa.gov 2018; Station IDs: 9410230, 9410660, and 9410840). Estuarine water levels were measured by various institutions as part of ongoing monitoring programs across the region, with sampling intervals ranging from $2 \mathrm{~s}$ to 30 min. Loggers included Teledyne RD-Instruments ADCPs (acoustic Doppler current profilers), Hobo pressure loggers, Sea-Bird CTDs (conductivity, temperature, depth), YSI 6600, EXO2 multiparameter sondes, Design Analysis Associates Inc. WaterLOG Microwave sensor, and RBR pressure loggers. Pressure sensor data were corrected for fluctuations in barometric pressure ("Atmospheric Data" section) and converted into water depth. All available data provided by agencies during the primary study period, November 1, 2015, to April 1, 2016, were used. Additionally, to provide historical context, data collected from October 1, 2004, to December 1, 2018, in LPL, TRE, and SDB were analyzed. Data from LPL and TRE were collected as part of the Tijuana River National Estuarine Research Reserve systemwide monitoring program (Station IDs: LPLNW and TJRBRWQ, respectively). SDB data were from a NOAA tide gauge (tidesandcurrents.noaa.gov 2018; Station ID: 9410170). Specific estuary data collection sampling schemes, quality control choices, instruments, and locations are outlined in the Appendix.

Absolute height (relative to a fixed geodetic datum, NAVD88, $\mathrm{m}$ ) of loggers was only known at six locations (Mugu Lagoon, Seal Beach, San Dieguito Lagoon, LPL, SDB, and TRE), where the sensor elevations were surveyed during the study period. Therefore, to provide a consistent relative datum (NAVD88, $\mathrm{m}$ ), the mean of the higher-high estuary water levels during open inlet phases, using all available data from September 1, 2015, to May 1, 2016, were adjusted to match the mean of the higher-high water levels at the nearest NOAA tide gauge over the same period for as the available lagoon data. The tidal phasing differences between the estuary and tide gauge were preserved. Only the higher-high tide was matched because it was least likely to be affected by frictional effects (e.g., Williams and Stacey 2016). Additionally, the height of high tide in the estuary has been shown to be approximately the height of the high tide in the estuary in a similar system (Hubbard 1996). This adjustment relies on the assumption that because these estuaries are short relative to tidal excursion, there is minimal setup or tidal dampening for the average higher-high water levels (Friedrichs 2010). The calculated vertical offsets from the adjustment were tested by employing the same adjustment for the six surveyed loggers with known absolute elevation, resulting in $0.04 \mathrm{~m}, 0.01 \mathrm{~m}, 0.08 \mathrm{~m}$, $0.02 \mathrm{~m}, 0.02 \mathrm{~m}$, and $0.06 \mathrm{~m}$ offsets (Mugu, Seal Beach, San Dieguito Lagoon, LPL, TRE, and SDB respectively). Note that these errors are consistently positive (albeit very small, all < $0.08 \mathrm{~m}$ ), suggesting a small mean estuary water-level setup relative to ocean water levels. Nevertheless, these offsets are near the vertical error of the Spectra Precision Epoch 50 or Leica RX1200 real-time kinematic network rover (RTK GPS) surveying equipment used (approximately $0.05 \mathrm{~m}$, although values vary with distances to base stations) and small compared to the range of average water levels for the different estuaries (Table 1) as well as the setup that can be experienced in small estuaries (Williams and Stacey 2016), indicating that this method is appropriate for converting all water level data into the NAVD88 datum within the measurement errors.

Water levels were subsampled to 15 min (subsequently referred to as tidal water levels) and higher-high water levels as well as lower-low water levels were extracted. A Godin low-pass filter was used to remove tidal, diurnal and other high-frequency variability (Walters and Heston 1982; 
Table 1 Estuary inlet and water level (WL) summary statistics. Infrastructure at mouth, variance in low-passed water levels, standard deviation of low passed water level, average low-passed water level elevation, $r$ and root-mean-squared error (RSME) values for measured estuaries water level vs. measured ocean water level (at nearest tide gauge) for all estuaries, and for the open-only state for ICEs that closed during this observational period. Gray shading indicates ICEs. Bold indicates statistically significant where $p<0.05$

\begin{tabular}{|c|c|c|c|c|c|c|c|c|c|c|c|c|c|}
\hline \multirow[b]{3}{*}{ Estuary } & \multirow[b]{3}{*}{$\begin{array}{l}\text { Mouth } \\
\text { State }\end{array}$} & \multirow{3}{*}{$\begin{array}{l}\text { Distance } \\
\text { Upstream } \\
\text { of Mouth }\end{array}$} & \multirow{3}{*}{$\begin{array}{c}\text { Estuary } \\
\text { Size, } \\
\text { hectares }\end{array}$} & \multicolumn{6}{|c|}{ Subtidal } & \multirow{2}{*}{\multicolumn{4}{|c|}{$\begin{array}{c}\text { Tidal } \\
\text { Estuary WL vs. Offshore WL }\end{array}$}} \\
\hline & & & & \multirow[b]{2}{*}{$\begin{array}{c}\text { WL } \\
\text { Variance }\end{array}$} & \multirow{2}{*}{$\begin{array}{c}\text { Average } \\
\text { WL } \\
\text { Elevation }\end{array}$} & \multicolumn{4}{|c|}{ Estuary WL vs. Offshore WL } & & & & \\
\hline & & & & & & $\mathbf{r}$ & RMSE & $\mathbf{r}_{\text {Open }}$ & $\begin{array}{c}\text { RMSE } \\
\text { Open }\end{array}$ & $\mathbf{r}$ & RMSE & $\mathbf{r}_{\text {Open }}$ & $\begin{array}{c}\text { RMSE } \\
\text { Open }\end{array}$ \\
\hline Mugu & Unarmored & $900 \mathrm{~m}$ & 830 & $0.006 \mathrm{~m}^{2}$ & $1.22 \mathrm{~m}$ & 0.83 & 0.28 & $\sim$ & $\sim$ & 0.86 & 0.19 & $\sim$ & $\sim$ \\
\hline Malibu & Unarmored & $450 \mathrm{~m}$ & 14 & $0.12 \mathrm{~m}^{2}$ & $1.94 \mathrm{~m}$ & 0.73 & 0.83 & -0.25 & 0.49 & -0.03 & 1.06 & 0.87 & 0.71 \\
\hline Los Cerritos & Jetty & $4310 \mathrm{~m}$ & 44 & $0.006 \mathrm{~m}^{2}$ & $0.81 \mathrm{~m}$ & 0.85 & 0.06 & $\sim$ & $\sim$ & 1.00 & 0.06 & $\sim$ & $\sim$ \\
\hline $\begin{array}{l}\text { Colorado } \\
\text { Lagoon }\end{array}$ & Jetty & $4700 \mathrm{~m}$ & 6 & $0.006 \mathrm{~m}^{2}$ & $0.95 \mathrm{~m}$ & 0.94 & 0.06 & $\sim$ & $\sim$ & 0.93 & 0.19 & $\sim$ & $\sim$ \\
\hline Alamitos Bay & Jetty & $4300 \mathrm{~m}$ & 236 & $0.010 \mathrm{~m}^{2}$ & $0.87 \mathrm{~m}$ & 0.89 & 0.05 & $\sim$ & $\sim$ & 0.97 & 0.13 & $\sim$ & $\sim$ \\
\hline Seal Beach & Jetty & $3300 \mathrm{~m}$ & 406 & $0.005 \mathrm{~m}^{2}$ & $1.01 \mathrm{~m}$ & 0.94 & 0.04 & $\sim$ & $\sim$ & 1.00 & 0.03 & $\sim$ & $\sim$ \\
\hline $\begin{array}{c}\text { Newport Back } \\
\text { Bay (NB) }\end{array}$ & Jetty & $6000 \mathrm{~m}$ & 655 & $0.008 \mathrm{~m}^{2}$ & $0.91 \mathrm{~m}$ & 0.98 & 0.03 & $\sim$ & $\sim$ & 1.00 & 0.04 & $\sim$ & $\sim$ \\
\hline $\begin{array}{c}\text { Santa } \\
\text { Margarita } \\
\text { Lagoon }\end{array}$ & Unarmored & $1100 \mathrm{~m}$ & 116 & $0.062 \mathrm{~m}^{2}$ & $1.47 \mathrm{~m}$ & -0.03 & 0.67 & 0.27 & 0.44 & 0.04 & 0.83 & 0.16 & -0.73 \\
\hline $\begin{array}{c}\text { Agua } \\
\text { Hedionda }\end{array}$ & Jetty & $750 \mathrm{~m}$ & 140 & $0.003 \mathrm{~m}^{2}$ & $0.88 \mathrm{~m}$ & 0.76 & 0.07 & $\sim$ & $\sim$ & 0.92 & 0.20 & $\sim$ & $\sim$ \\
\hline San Dieguito & Unarmored & $750 \mathrm{~m}$ & 56 & $0.013 \mathrm{~m}^{2}$ & $1.09 \mathrm{~m}$ & 0.55 & 0.24 & $\sim$ & $\sim$ & 0.73 & 0.40 & $\sim$ & $\sim$ \\
\hline $\begin{array}{c}\text { Los } \\
\text { Peñasquitos } \\
\text { (LPL) }\end{array}$ & Unarmored & $750 \mathrm{~m}$ & 96 & $0.119 \mathrm{~m}^{2}$ & $1.44 \mathrm{~m}$ & -0.26 & 0.68 & 0.64 & 0.33 & 0.23 & 0.80 & 0.64 & 0.04 \\
\hline $\begin{array}{l}\text { San Diego Bay } \\
\text { (SDB) }\end{array}$ & Jetty & $9900 \mathrm{~m}$ & 6050 & $.008 \mathrm{~m}^{2}$ & $0.83 \mathrm{~m}$ & 0.98 & 0.05 & $\sim$ & $\sim$ & 1.00 & 0.06 & $\sim$ & $\sim$ \\
\hline $\begin{array}{l}\text { Tijuana } \\
\text { Estuary (TRE) }\end{array}$ & Unarmored & $900 \mathrm{~m}$ & 224 & $0.011 \mathrm{~m}^{2}$ & $1.11 \mathrm{~m}$ & 0.57 & 0.26 & 0.62 & 0.25 & 0.76 & 0.40 & 0.77 & 0.35 \\
\hline
\end{tabular}

Thomson and Emery 2014). These subtidal, low-pass, filtered water levels will subsequently be referred to as "detided" water levels, so as to not provide confusion with the use of "subtidal" common in estuarine ecology. In Mugu and Malibu Lagoons, the sensors were deployed above local lower-low water and were dry during the low tides. For these time periods, the low-pass filtering biased the detided estuary water level high. In the subsequent analyses, higher-high water levels are a metric to address flooding and inundation, lower-low water levels are used to assess perching at sills, and detided water levels are used to address the mean state.

Pearson's correlation coefficients $(r)$ were computed for various parameters and assumed to be statistically significant if $\mathrm{p}$ was less than or equal to 0.05 ( $95 \%$ confidence limits). $p$ value calculations use effective degrees of freedom $\left(\mathrm{N}_{\mathrm{eff}}\right)$ based on integral time scales (Emery and Thompson 2014).

\section{Wave Data}

Offshore wave statistics were provided from the Coastal Data Information Program (CDIP) buoy network. Nearshore wave statistics including significant wave height and peak wave direction were extracted from the CDIP Monitoring and Prediction (MOP) System model output (O'Reilly and Guza
1993; O'Reilly et al. 2016; cdip.usd.edu 2018). MOP uses a numerical wave model to propagate deep-water buoy observations to the $10-\mathrm{m}$ isobath approximately every $100 \mathrm{~m}$ in the alongshore. All hindcast data were reported hourly. The nearest MOP line to either the given NOAA tidal gauge or center of the estuary mouth was used for each respective site as labeled in theAppendix.

\section{Atmospheric and River Discharge Data}

Barometric data were from either the nearest NOAA tide gauge or pressure sensor deployed at the estuary as specified in the Appendix. Precipitation data were from airport stations. Weather stations are marked on Fig. 1. River discharge from Los Penasquitos Creek gauge (Waterdata.usgs.gov. 2018: Gauge 11023340).

\section{Inlet State in ICEs and Sill Elevation Measurements in Los Peñasquitos Lagoon}

Mouth state (open or closed) in the ICEs was determined by examining water level records. Closures were characterized by periods without tidally varying water levels. When 
available, satellite imagery data from Planet.com and/or mouth imagery were used to verify mouth state.

High-resolution topo-bathymetry transects were conducted at LPL using a Spectra Precision Promark 700 GNSS realtime kinematic network rover (RTK GPS) and Scripps Orbit and Permanent Array Center (SOPAC) base station (SIO5) corrections. Eleven inlet elevation surveys were conducted between November 1, 2015, and April 1, 2016. Surveys were performed manually at lower-low tides following radial transects around the curving lagoon inlet. Measurements were not collected if the water level was greater than $1 \mathrm{~m}$, or if the seafloor substrate or tidal currents inhibited data collection. Two surveys were conducted, one on the seaward side of the road embankment and bridge that defines the inlet, and the other on the landward side of the road embankment and bridge. Surveys were objectively mapped into $8-\mathrm{m}$ cells using inverse difference weighted interpolation. The sill elevation was defined as either the average height of the seaward side or the landward side of the road embankment (see the "Morphodynamics in ICEs" section, Fig. 6). To determine sill changes over shorter time periods, we extracted the estuary lower-low water level as a proxy for sill height and validated it against our topo-bathymetric surveys. Imagery from timelapse cameras installed near the mouth was used to qualitatively assess the sill migration and accretion over time.

\section{Results}

\section{Ocean Conditions During 2015-2016 El Niño}

Water levels off the coast of Southern California were persistently above average throughout the strong 2015-2016 El Niño (Fig. 2a, Supplementary Fig. 1). The maximum monthly average ocean water levels were $0.20 \mathrm{~m}, 0.20 \mathrm{~m}$, and $0.21 \mathrm{~m}$ above the predicted levels for La Jolla, Los Angeles, and Santa Monica, respectively (La Jolla in Fig. 2a). Marked wave events occurred on several occasions through the winter (Fig. 3) with the largest waves predominantly from the northwest; thus, the southern estuaries were more exposed to wave forcing due to the coastline geometry and the effect of islands within the Southern California Bight (Fig. 1).

Maximum detided ocean water levels during the study period occurred during extreme wave events and were $0.31 \mathrm{~m}$, $0.30 \mathrm{~m}$, and $0.31 \mathrm{~m}$ above the NOAA predicted detided water levels for La Jolla, Los Angeles, and Santa Monica, respectively (Fig. 2a). Winter coastal water levels were positively correlated with the Godin filtered significant wave heights $(r=0.39,0.33,0.28 ; p=0.04,0.06,0.13$ with $1.2,1.3$, 1.1 day lag of waves behind water levels) and negatively correlated with the barometric pressure $(r=-0.72,-0.67,-$ $0.73 ; p<0.01,<0.01,<0.01$ with $0.0,0.2,0.2$ day lag of barometric pressure behind water levels).
At the San Diego Airport, there were 3 precipitation events with two-day rainfall totals over $10 \mathrm{~mm}$ (Fig. 2d), below the average of 5.8 precipitation events per year from 1939 to 2018 , consistent with other precipitation gauges in coastal Southern California. The total precipitation at San Diego Airport during the winter of 2015-2016 was about $21 \%$ below average (40th percentile of the winter historical rainfall totals from 1939 to 2018) (ncdc.noaa.gov, Station ID: USW00023188). This lower than average mean rainfall and rainfall events is consistent with rainfall patterns throughout Southern California during the 2015-2016 winter (e.g., Lee et al. 2018; Siler et al. 2017).

\section{Estuary Water Levels}

\section{Representative POEs: San Diego Bay and Newport Bay}

During the 2015-2016 winter, the tidal water levels in SDB and NB (Fig. 3a) were strongly correlated with the ocean water levels $(r>0.99, p<0.01$, and $r>0.99, p<0.01)$ for both SDB and NB; Table 1). The detided water levels (Fig. 3b) were also strongly correlated with ocean detided water levels for SDB and NB $(r=0.98, p<0.01$, and $r=0.98, p<0.01$, respectively). The strong, significant correlations between ocean and estuarine water levels in SDB during the 2015-2016 winter were consistent with those found in a historical comparison of tidal $(r>0.99, p<0.01)$ and detided $(r=0.94, p<0.01)$ water level data from 2005 to 2018 (Fig. 4c, d).

\section{Representative ICEs: Tijuana River Estuary and Los Peñasquitos Lagoon}

In both TRE and LPL, sills comprised of sand and cobbles grew over the 2015-2016 winter and restricted flow or closed the respective inlets for brief periods of time (Fig. 6 and discussed further in the "Inlet Closures in ICEs" and "Sill Elevation Changes over Time in Los Peñasquitos Lagoon" sections). During the open states, hydraulic and frictional control at the sills contribute to truncated lower-low water levels (see Fig. 3a for LPL, red line relative to gray) and to elongated ebbs (Figs. 3a and 4a). The sills resulted in reduced maximum tidal ranges $(1.55 \mathrm{~m}$ and $1.37 \mathrm{~m}$, for TRE and LPL, respectively) compared with ocean ranges ( $2.56 \mathrm{~m}$ at La Jolla) and contributed to lower, yet significant, correlations between ocean and estuarine water levels when the estuary mouth was open $(r=$ $0.77, p<0.01$, and $r=0.64, p<0.01$; Table 1). As a result of the lower-low tide truncation and perching, detided water levels in TRE and LPL (Fig. 3b) were not strongly correlated with detided ocean water levels during the winter observation period, even when restricting the analysis to only open periods ( $r=$ $0.57, p=0.09 ; r=-0.26, p=0.50$ for all periods; $r=0.64, p=$ $0.09, r=0.62, p=0.06$ for open periods for TRE and LPL, respectively; Table 1). During large wave events, entrance sills 
Fig. 2 Regional conditions in southern California. (a) Twentyfour-hour low-pass water level anomaly (observed minus predicted) at the La Jolla tide gauge (tidesandcurrents.noaa.gov 2018, Station ID: 9410230). (b)

Twenty-four-hour low-pass filtered significant wave height from the MOP hindcast line closest to the La Jolla tide gauge (cdip.ucsd. edu 2018, Station ID: D0589). (c) Twenty-four-hour low-pass barometric pressure at the La Jolla tide gauges. (d) Daily precipitation from San Diego Airport (ncdc.noaa.gov 2018, Station ID: USW00023188)

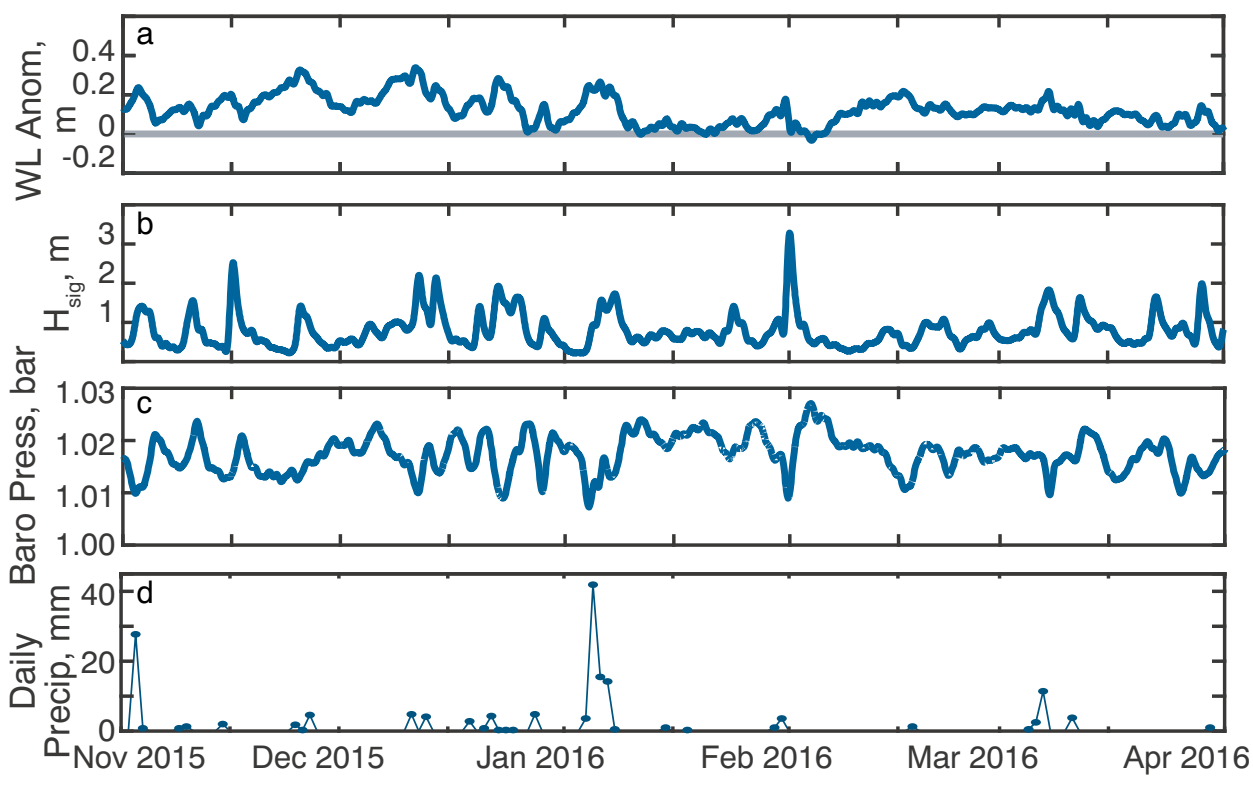

accreted causing truncated (i.e., higher) tidal low-water levels, resulting in elevated detided water levels and thus a decoupled and not statistically significant (at the 95\% confidence level) response to ocean water levels (Fig. 4b). These trends were consistent with those found in a historical analysis of water level data in TRE and LPL (2005-2018, see Fig. 4 b and c). In both systems, the open-period tidal water levels were less correlated than those in SDB $(r=0.74, p<0.01 ; r=0.38$, $p<0.01$, for TRE and LPL, respectively) and the detided water levels were not correlated $(r=0.48, p=0.06 ; r=0.09, p=0.39$, for TRE and LPL, respectively).

\section{Comparison of Water Levels in ICEs and POEs}

Results from all 13 estuaries are consistent with observations from the representative estuaries: tidal water levels in the POEs are more strongly correlated $(0.92$ $<r<1.00 ; p<0.01)$ with the ocean water levels than the
Fig. 3 Water levels and ocean waves. (a) Tidal water levels in Los Peñasquitos Lagoon (red thin), Newport Bay (blue thick), and offshore in the coastal ocean (gray thin). (b) Detided water level for all 13 estuaries during the observational period. Red, thin lines indicate intermittently closed estuaries (ICEs) while blue, thick lines indicate perennially open estuaries (POEs) and the thick gray line indicates ocean water level. Estuary lines are shaded from North (lightest) to South (darkest). Dots on a and b indicate mouth state changes to closed (filled) or open (open). (c) MOP hindcast of significant wave height at Los Peñasquitos Lagoon (red thin) and Newport Bay (blue thick) mouths
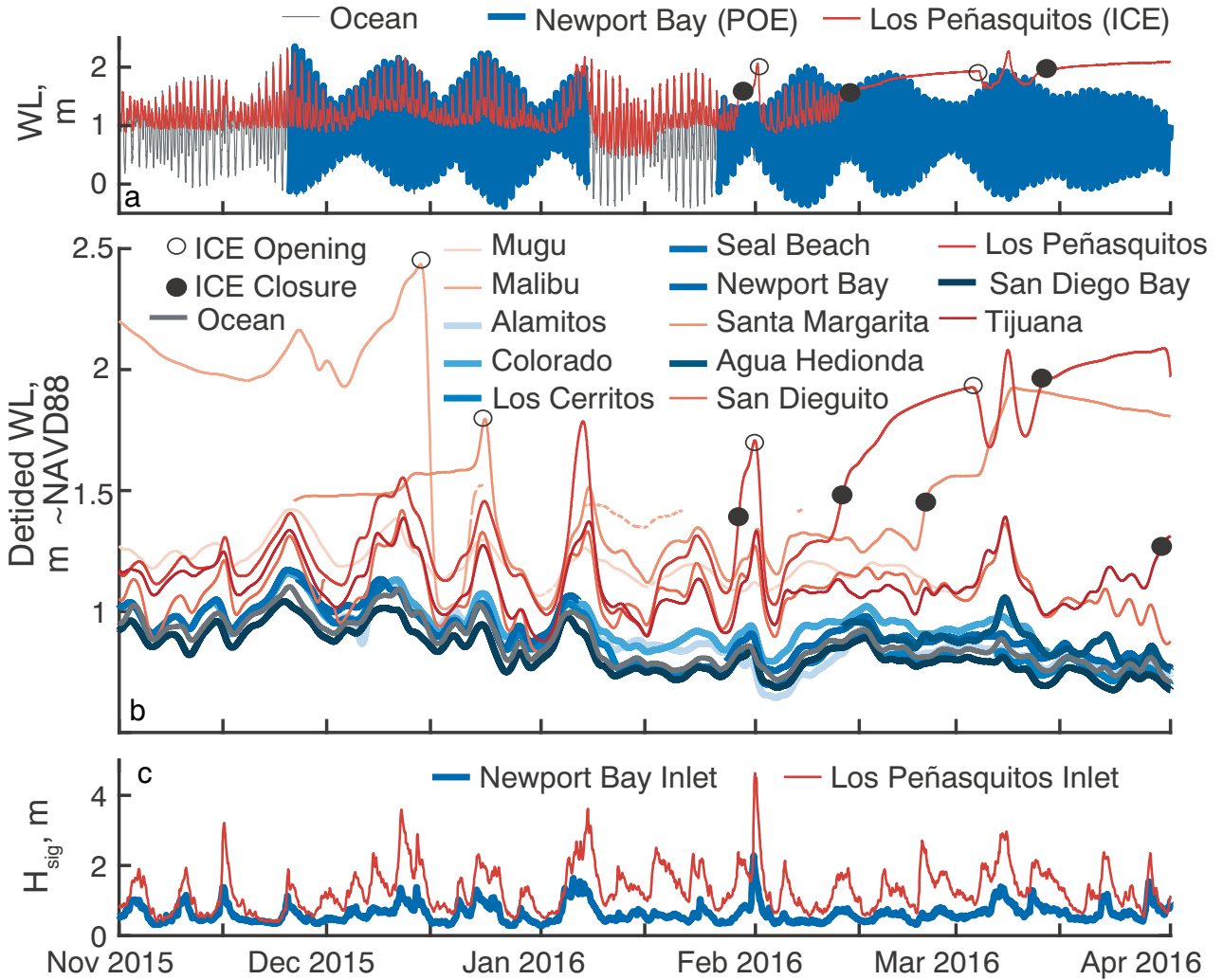
Fig. 4 Two-dimensional histograms of ocean water level versus estuary water level for open-mouth periods. (a) Histograms based on tidal water levels for 6 ICEs and for 7 POEs, using all available 2015-2016 winter data. (b) As in (a), but for detided water level data. (c) Histograms based on tidal water levels for LPL and for SDB, using all available data from 2005 to 2018. (d) As in (c), but for detided water level data. ICEs are indicated in red and POEs in blue where the colored contours (color bars at the bottom) indicate percentage occurrence for each ocean and estuary water level value
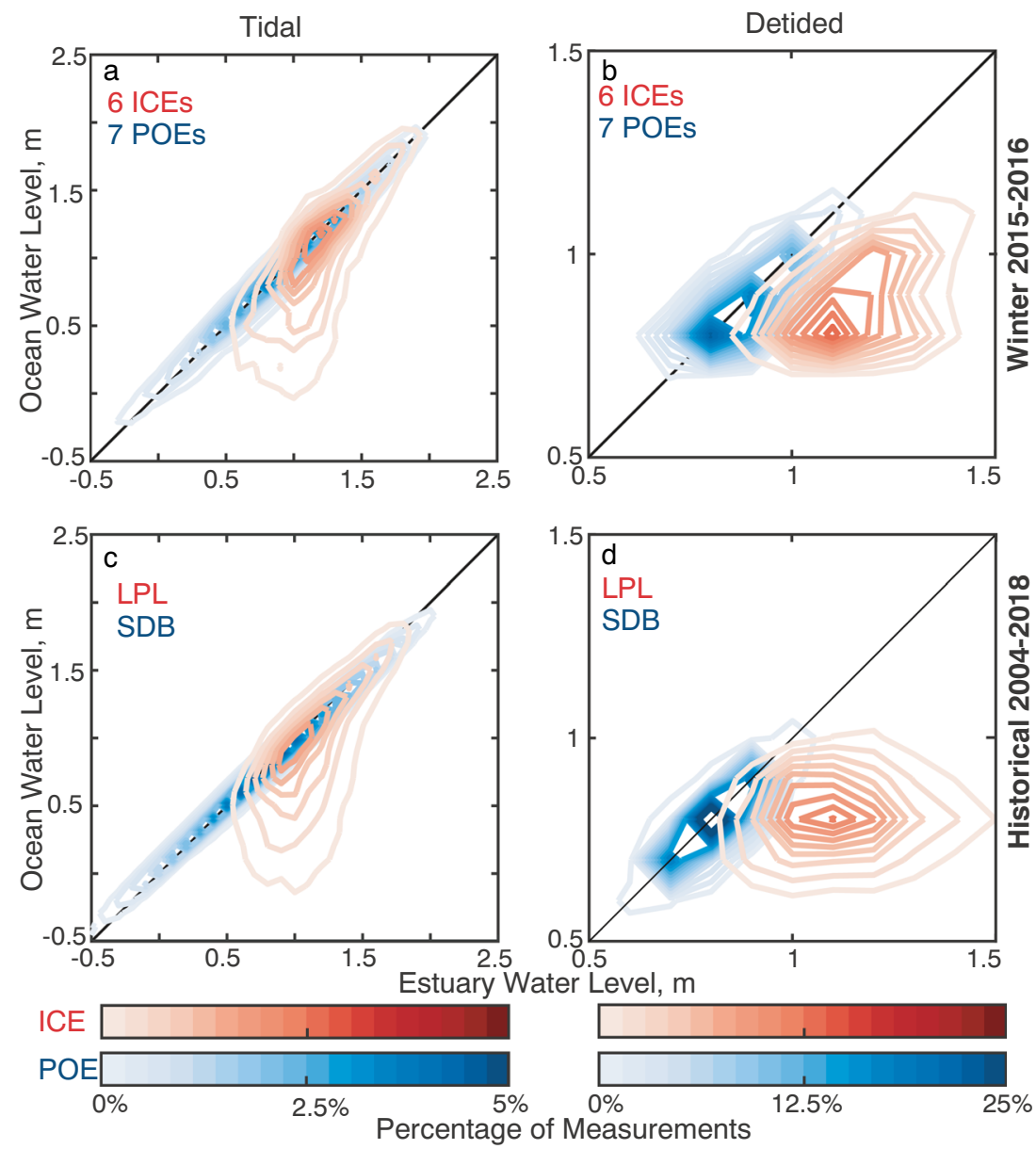

ICEs $(-0.03<r<0.86 ; 0.0<p<0.89$ for all periods; $0.16<r<0.87 ; p<0.01$ for open periods) (Table 1 and Fig. 4a). Subtidal water levels for the observation period were highest in the ICEs that closed, followed by the ICEs that remained open for the study period, with the POEs maintaining the lowest mean water levels (Fig. 3b, Table 1). In Mugu and Malibu, the sensors were dry at the low tides causing the average water levels to be biased high. During open periods, most of the ICE detided water levels had a higher variance than POE detided water levels (Table 1, Fig. 3b). Moreover, most ICE detided water levels were not significantly correlated (at the 95\% confidence level) with ocean water levels (Table 1, Fig. 4b) suggesting that detided ICE water levels had a decoupled response due to perched tidal low-water during large wave events and high ocean water levels.

Higher-high water level deviations from the ocean (estuary higher-high water minus ocean higher-high water level) are plotted against significant wave heights at the closest MOP lines to the estuary mouths to assess additional water level setup or setdown within the estuaries when the mouths are open (Fig. 5, similar to Williams and Stacey 2016, Fig. 5e). In the POEs, there is no significant relationship between wave height and higher-high water level deviation from the ocean $(r=-0.13, p=0.49)$, while in the ICEs, there is a clear relationship $(r=0.52$, $p<0.01)$. It is important to note that Fig. 5 includes the higher-high water correction to NAVD88 explained in the "Water Level Data" section. Therefore, the absolute elevation differences may be offset upwards along the $y$-axis relative to Fig. 5 (upwards because of the persistent positive mean higher-high water level difference found for all sensors with known absolute elevation). However, it is important to note that repeating Fig. 5 with absolute elevation (for those estuaries for which it exists, not shown), the higher-high water level differences remain negative (i.e., a setdown) during low wave conditions, although vertical survey errors and varying distance upstream of the sensor locations complicate these results.

\section{Inlet Closures in ICEs}

During complete inlet closures, water levels in ICEs increased because the sill blocked outflows while inflows from freshwater upstream continued (Fig. 7). In 


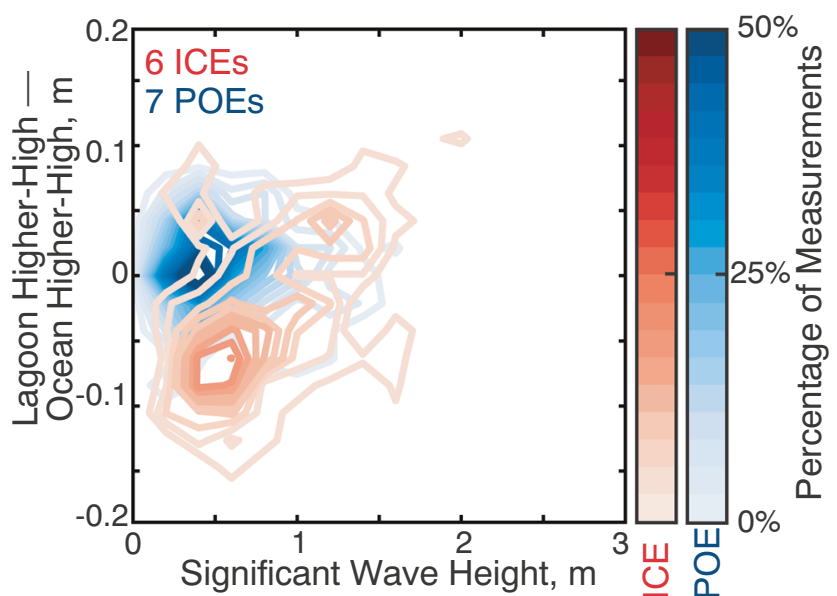

Fig. 5 Two-dimensional histogram of estuary higher-high water level minus ocean higher-high water level vs. significant wave heights at the closest MOP lines to the estuary mouths. ICE data are only from times when the mouth is open. A positive (negative) value on the y axis would indicate a setup (setdown) inside of the estuary relative to the ocean if the absolute elevations were exact. ICEs are indicated in red and POEs in blue where the color bars and contours indicate the percentage occurrences at each wave height and water level for all available ICE and POE data during open periods in 2015-2016

addition, in some circumstances, wave overtopping contributed to increased water levels behind the sill which we can deduce from time-lapse imagery and high frequency pressure measurements (not shown). During the observation period, Malibu Lagoon was closed for 30 days and naturally reopened; LPL was closed for 36 days, naturally reopened once, but closed again and was mechanically breached three times; TRE was closed for 13 days (starting at the end of the study period) and was mechanically breached; Santa Margarita Estuary was closed for 44 days and naturally reopened (Fig. $3 b)$.

\section{Sill Elevation Changes over Time in Los Peñasquitos Lagoon}

For the LPL mouth, we have morphology data which show that LPL experienced 0.5 to $2 \mathrm{~m}$ of accretion (Fig. 6) in the inlet region over the course of the winter season, in addition to nearly $1 \mathrm{~m}$ of erosion of a man-made embankment protecting the estuary marsh further upstream. Although measurements were not taken at a high-enough frequency to capture changes on the time scales of tides or storms, time-lapse imagery and in-person observations show that the channel migrated between hardened structures and that the sill migrated within the inlet area (Fig. 6 a and b) and changed elevation throughout the study period. Importantly, imagery indicates that inlet accretion occurred episodically and typically coincided with periods of large offshore waves (consistent with Behrens et al. 2013).
From the morphological data, we can track the elevation of the beach constricting flow through the mouth seaward of the road embankment as well as the elevation of the flood-tide shoal landward of the road embankment (described in the "Inlet State in ICEs and Sill Elevation Measurements in Los Peñasquitos Lagoon" section and indicated on Fig. 6). These data show that the average elevation of the controlling sill, whether on the landward (estuary) or seaward (beach) side of the road embankment, was well represented by day-to-day changes in the lower-low water level. Before the closure, the elevation landward of the road embankment (dark blue in Figs. 5 and 6) best matched this metric (with the exception of a survey immediately following a large flushing event). However, during the closure, the elevation seaward of the road embankment (light blue in Figs. 6 and 7) more closely matched the lower-low water level. Overall, the average sill elevation measured by the topo-bathymetric surveys (taken at the appropriate location) matched the estuary lower-low water level with statistical significance (Fig. $7 \mathrm{~b} ; r=0.92$, $\mathrm{RMSE}=0.16 \mathrm{~m}, p<0.05$ ).

\section{Discussion}

\section{El Niño and Implications to Future Conditions}

During the 2015-2016 El Niño, elevated ocean water levels (Fig. 2a), large wave events (Fig. 2b), and low precipitation (Fig. 2d) along the Southern California coast provided the opportunity to understand how low-inflow estuaries respond to oceanic forcing. The coastal water levels were weakly correlated with the low-pass filtered significant wave heights (Fig. 2b) and more strongly correlated with the barometric pressure (Fig. 2c). The high correlation with barometric pressure was likely due to a combination of the effects of storm surge, waves, and changes to local offshore winds and currents caused by local storms. High coastal California water levels caused elevated estuarine water levels resulting in an increased frequency of inundation of tidal wetlands during the El Niño (Goodman et al. 2018). As extreme coastal water level events are likely to increase in the future (Tebaldi et al. 2012; Sweet and Park 2014), as discussed in the introduction, it is expected that low-inflow estuaries will also experience more extreme water level events in the future. The analyses provided here may provide some insights into how these estuaries in Southern California, and low-inflow estuaries around the world (Largier et al. 1996) might respond to future conditions.

\section{Morphodynamics in ICEs}

Significant morphological changes near the mouth were observed in most of the ICEs during the observation period. In LPL we found that significant accretion occurred and that we 

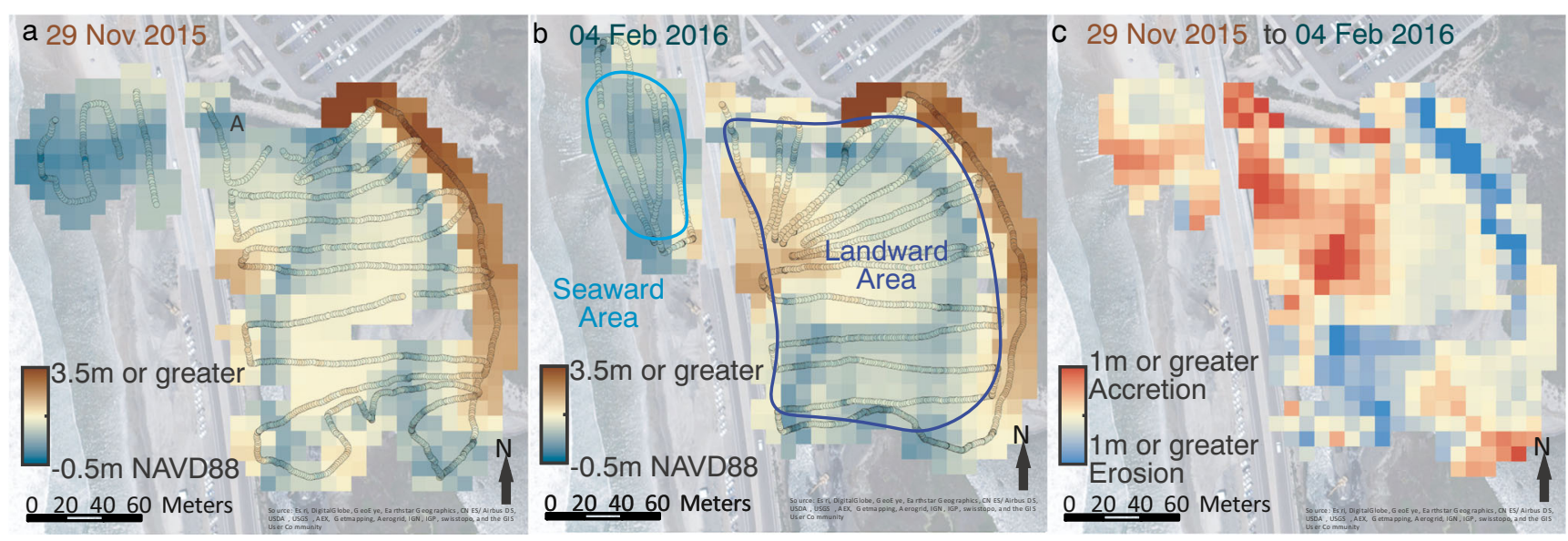

Fig. 6 Los Peñasquitos Lagoon topo-bathymetry surveys on (a) 29 November 2015 and (b) 4 February 2016 - circles indicate measurement locations; data gridded into 8-m cells using inverse difference weighted interpolation. Lines on $\mathrm{b}$ delineate the two averaging areas for estimating

could use lower-low water levels to approximate sill elevation changes over time. As such, we can use the lower-low water level to examine the interactions between sill height and ocean events. Through comparisons with imagery, site visits, and surveys, we found that (with the exception of one survey following an unusually large flushing event), when the system was open or constricted, the lower-low water level more closely matched the average height of the landward, estuary area (dark blue in Figs. 5 and 6), while during the closure, the average height of the seaward, beach area (light blue in Figs. 5 and 6) more closely matched the lower-low water level. This is attributed to the sill location moving westward past the constriction caused by the manmade berm and bridge. The lower-low water levels at the other studied ICEs (and available imagery) show that morphological changes occurred in most of the ICEs studied.

Enhanced sill accretions and more frequent and persistent closures were observed in ICEs in Southern California during the 2015-2016 El Niño season. Los Peñasquitos Lagoon sill height: seaward, "beach area" (light blue) and landward, "estuary area" (dark blue)—see Fig. 7. (c) Difference between surveys where red is deposition (accretion) and blue is erosion

closed for more days than it had in the past 25 years (Young et al. 2018 which builds off a historical record of closure frequency in Hastings and Elwany 2012). Additionally, the Tijuana River Estuary, which closed for the first time since the previous large El Niño in 1982-1983 (Ludka et al. 2016; Young et al. 2018). The a typical closures can be attributed to the anomalously large wave conditions coupled with the low precipitation (as expected from e.g., Behrens et al. 2013; Rich and Keller 2013). In both LPL and TRE, multi-year water level records indicate that sill heights (applying the lowerlow water metric) generally increased during large wave events and decreased during significant flushing events. Additionally, years with larger wave events had higher estuarine water levels, higher sills, and more closure days (Supplementary Fig. 2). Unfortunately, sparse data and periodic dredging precluded further analysis. In the four southern ICEs, the sill heights increased during the largest wave events of the study period. Large waves and the alongshore migration of beach nourishment sand (Ludka et al. 2018) are likely

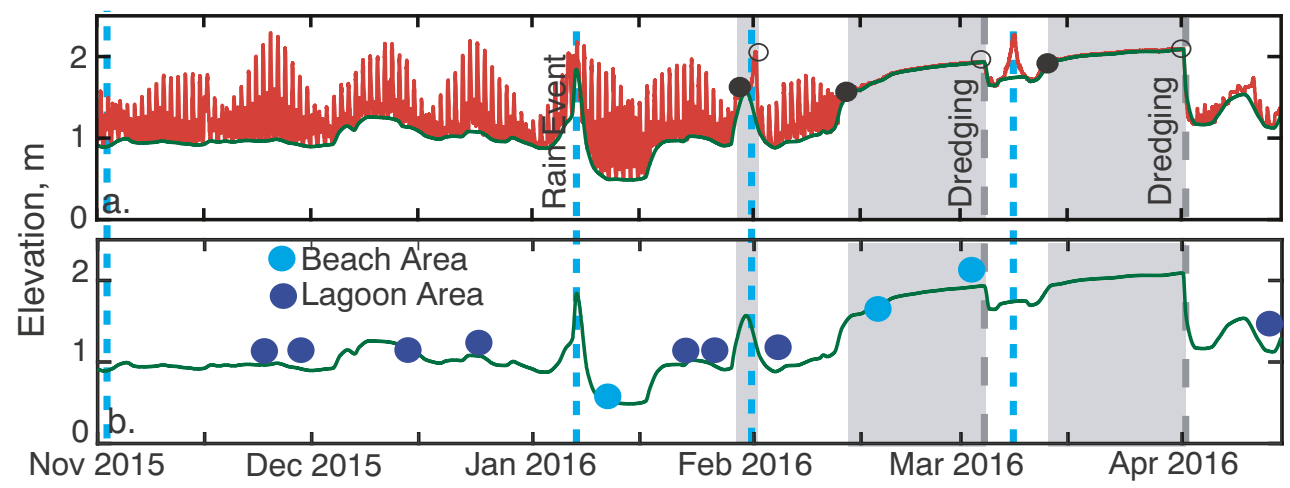

Fig. 7 (a) Tidal water level of Los Peñasquitos Lagoon (red) and lowerlow water level (dark green). Major precipitation events (light blue, dashed) and mouth dredging events (gray, dashed) are marked with vertical lines. Dots indicate mouth state changes to closed (filled) or open

(open). Gray shading indicates closed periods. (b) Lower-low water level (as in (a)) and average elevation of beach (light blue) and estuary (dark blue) areas as demarcated in Fig. 5 
responsible for the 2016 closure at TRE. Both TRE and LPL were artificially breached during the 2015-2016 El Niño; had the systems not been breached, the water levels in the systems would have been elevated for an even longer period.

\section{Comparison of ICEs and POEs}

Comparative analyses of different low-inflow estuaries are relatively rare with the exception of a few recent studies (e.g., McSweeney et al. 2017; Goodman et al. 2018; Clark and O'Connor 2019) and are complicated by system-specific dynamics and human alterations. Comparing water levels across a range of estuaries experiencing similar oceanic and upstream forcing over the same timeframe has allowed us to further our understanding of how ICEs and POEs respond to ocean water level events. The detided water levels in POEs mirrored ocean water levels both in mean water level and variance while the detided water levels in ICEs were higher on average and had a higher variance than ocean water levels. The mean water levels in the ICEs were higher because the sill height at the ICE mouths dictates the lower-low water level and thus elevates the detided and average water levels in these systems. In addition, higher-high water levels in ICEs increased with increasing ocean wave height (Fig. 5 and discussed further below) additionally contributed to higher detided water levels in ICEs, although the magnitude is less than the sill truncation contribution. The higher variance of the ICE detided water levels is caused by the sill blocking off low tides and reducing the range of tidal water levels within the estuary. This results in extreme water level events and springneap variability being more pronounced (relative to the mean water level) in the detided water levels in the ICEs than they are in POEs. The sill height changing over time further increases the variability of the tidal and detided water levels. Overall, ICEs have a more decoupled response to high ocean water levels than POEs, a result that our data suggests is largely due to mouth morphology, and to a lesser extent, geometry, including system size, depth, and marsh area (Friedrichs 2010). Assessing and decoupling contributions from the different components of the total water level (e.g., waves versus barometric pressure versus longer term elevated ocean water level effects versus river flow events) was difficult. Historical data from LPL and TRE indicate that flooding plays an important role in the water level in ICEs as water levels were high during large river flow events (Supplementary Fig. 2).

Discerning the effects of marsh extent and mouth morphology with this limited dataset is challenging because in Southern California, ICEs are generally more natural systems with higher percentages of marsh while POEs are generally more heavily managed and channelized (Appendix). The overall trends seen in Fig. 3b suggest that the percentage of marsh extent impacts water levels inside of these estuaries.
Moreover, the analysis of higher-high water level setup and setdown in ICEs (which on average have more marsh) in response to ocean waves, suggest there may be a marsh influence. However, in a direct comparison between estuaries with similar percentages of marsh habitat (e.g., Seal Beach and Mugu), it appears that mouth morphology (i.e., the presence/ absence and size of a sill) plays a more important role in setting the mean estuarine water levels.

Data from the El Niño shows that detided water levels in ICEs increase more than detided water levels in POEs during large wave events (Fig. 3). Historical data at LPL, TRE, and SDB indicate that higher water levels in ICEs occurred more commonly during periods of large waves than during periods of high ocean water level anomalies suggesting wave-driven sill accretion (e.g., Ranasinghe et al. 1999; Behrens et al. 2013; Rich and Keller 2013) and wave setup (e.g., Malhadas et al. 2009; Williams and Stacey 2016) play an important role in ICE water levels (Supplemental Fig. 2). The sill height generally accretes during large wave events, truncating the lower tides, which causes the detided water levels to increase. The difference between the higher-high water levels in the estuaries and the ocean show that a larger water level setup (as high as $0.2 \mathrm{~m}$, but typically much smaller) occurs in ICEs than in POEs during high wave events (Fig. 5, similar to Williams and Stacey 2016, Fig. 5e). This is also consistent with the offset error estimates ("Water Level Data" section) being consistently being positive (albeit very small, all < $0.08 \mathrm{~m}$ ), suggesting that time mean ICE higher-high water levels were slightly elevated compared with ocean higherhigh water levels. Moreover, ICEs exhibit an estuarine setdown during low wave conditions, likely due to tidal amplitude attenuation in these highly frictional estuaries (Friedrichs 2010). Finally, ICEs show a positive, statistically significant linear relationship between estuarine setup and wave height, where higher-high water level in the estuary increases by $0.07 \mathrm{~m}$ above that of the ocean for every $1 \mathrm{~m}$ increase in wave height $(r=0.52, p=0.002)$, while POEs do not (Fig. 5).

The geographical location of ICE and POEs complicates the assessment that ICEs have more enhanced detided water levels and setup than POEs during large wave events because the geometry of the Southern California Bight (Cao et al. 2018) dictates the amount of wave energy (MOP wave roses, Fig. 1) and the peak wave direction at the estuary mouth. Nearly all POEs are to the north, where the waves at their mouths were smaller during this study due to regional shadowing. The only POE exposed to large waves is Agua Hedionda where a shorter dataset unfortunately limits the number of large wave events to only one (only 1 event where $H_{\text {sig }}>2 \mathrm{~m}$ for more than $1 \mathrm{~h}$ ). However, it is worthwhile to note that Agua Hedionda experienced some inlet accretion over this study period, likely resulting from its exposure to larger 
waves. Due to the geometry and the offshore islands of the Southern California Bight (Fig. 1), geographic location and wave shadowing play a large role in the wave conditions seen at the estuary mouths and the water level response within the estuaries to offshore events.

\section{Low-Inflow Estuary Management Implications}

Managers of low-inflow estuaries (whether ICEs or POEs) want to understand how sea level rise might affect their systems (Thorne et al. 2017) to develop effective resiliency and restoration strategies (Southern California Wetlands Recovery Project 2018). The effects of sea-level rise on marshes and wetlands (e.g., changes in accretion, migration, species composition, etc.) are currently a focus of several studies (e.g., Thorne et al. 2016).

Tidal prism is an important metric for many managers because it can help maintain open inlets (Hastings and Elwany 2012) and is important for marsh habitat. As sea levels rise, it is expected that POE water levels will increase proportionately because POE water levels mirror ocean water level fluctuations. Assuming that the bed elevations of POEs remain constant (through continued dredging and jetties), with higher sea levels, tidal prisms will increase (Holleman and Stacey 2014). In ICEs, however, the effect of sea-level rise on tidal prism is complicated by mouth morphodynamics and sill height elevation changes. Therefore, continued observations of sill heights in a variety of systems may provide additional understanding to how ICEs respond to changing conditions.

Managers of these systems are also interested in how the frequency of inundation and closures will change with future conditions. During the 2015-2016 El Niño, tidal marshes in estuaries all along the west coast experienced increased inundation (Goodman et al. 2018), a trend that is likely to continue with increased sea levels in both POEs and ICEs. During open conditions, the higher detided water levels in ICEs lead to a range of absolute elevations being inundated for longer than POEs which may impact the species that are able to thrive at those elevations (e.g., Janousek et al. 2016; van Belzen et al. 2017). Sustained high water in NB resulted in die-off of high marsh habitat that has been used previously as nesting habitat for several sensitive bird species (Dick Zembal, personal observations). If closures become more frequent, as they did during the El Niño conditions, the ICEs will experience an increased frequency of inundation of freshwater on saline habitats, hypoxic conditions (e.g., Gale et al. 2006; Cousins et al. 2010), prolonged periods of inundation at a fixed elevation, and would pose a greater risk to upstream flooding. More frequent inlet closures cause a shift from more saline marsh vegetation to more freshwater vegetation as the surface layer over the marsh is fairly fresh due to urban runoff (Los Peñasquitos
Lagoon Foundation et al. 2016). Additionally, reduced tidal prism would cause physiologically stressful conditions and a reduction of incoming marine propagules leading to changes in species composition and an overall reduction in diversity of plants and animals (Teske and Wooldridge 2001; Phlips et al. 2002; Raposa 2002; Saad et al. 2002). In Southern California, mouth closures in TRE and LPL typically result in hypoxia and subsequent fish kills within days as observed during the 2015-2016 winter (Crooks, personal observations). The risk for upstream flooding and inundation-including nearby infrastructure-increases during closures as the estuaries slowly fill due to urban runoff, precipitation, riverflows, and wave overtopping (Largier et al. 2019).

Low-inflow estuaries in Southern California, and around the world, are all managed by different entities with varying priorities, stakeholders, and economic and ecological values (e.g., Zedler and Kercher 2005; Adams 2014; Pratt 2014; McSweeney et al. 2017). As different management entities develop resiliency or restoration plans (e.g., Thorne et al. 2017) for their respective systems, they will likely take sea-level rise into account. This study demonstrates that water level response (and therefore appropriate management strategies) will vary by system. In more perennially open systems, it is expected that the water levels near the mouth will continue to match ocean water levels with upstream water levels depending on the geometry, bathymetry, and armoring in the system (e.g., Holleman and Stacey 2014). Although, even in some of the POEs (e.g., Agua Hedionda) inlet accretion occurs over longer time scales and could result in the water levels having a more similar response to those in ICEs. In ICEs, the detided water level response to increased sea levels will likely be non-linearly amplified; however, more unknowns particularly with regard to wave climate, sill accretion, marsh response, and changes in tidal prism suggests resiliency plans may need to account for an array of possible futures. As these ICE systems are generally more natural, the ecological consequences of increased water levels may be greater. Managers must weigh the tradeoffs between allowing for extreme water levels and more frequent closures and the cost and impacts of management and dredging (Largier et al. 2019). The plans would also benefit from being adaptable to evolving predictions and interannual variability. For example, if water levels increase and there is a decrease in large wave events it is possible that an increased tidal prism would lead to less frequent closures. Additionally, inlet maintenance permitting agencies may wish to allow estuary managers to recognize that elevated sill height and large forecasted waves may lead to an inlet closure and provide more permitting options that enable managers to use this knowledge to schedule maintenance and dredging activity in advance. 


\section{Summary}

Anomalous conditions associated with the 2015-2016 El Niño along the Southern California coastline including elevated ocean water levels, high waves, and low precipitation, provided the opportunity to understand how lowinflow estuaries respond to oceanic forcing and insights into how they might respond to changing ocean conditions. From November 2015 to April 2016, water levels were continuously measured in 13 estuaries in Southern California providing a unique dataset. Water levels from such a wide range of systems experiencing similar forcing conditions are rarely measured simultaneously. Of the 13 systems measured, 6 were ICEs and 7 were POEs. Generally, the water levels in the POEs (tidal and detided) were more closely correlated with ocean water levels. ICE water levels exhibited weaker correlations to ocean water levels due to a sill resulting in a decoupled detided response. ICEs also exhibited a relationship between high waves and higher-high-water levels, with low wave conditions exhibiting decreased higher-high water within ICEs compared to offshore, likely due to frictional damping, and high wave conditions exhibiting increased higher-high water within ICEs compared to offshore. While estuary-specific dynamics, geographic location, and human modifications complicated comparisons across estuaries, our analyses suggest that large wave heights were one of the most important factors driving the ICE response which appears closely linked to changes in mouth morphology, specifically sill accretion. Results suggest that ICEs worldwide may be more susceptible to altered water levels as well as morphological changes resulting from sea-level rise and higher wave heights. A metric for sill height provides a starting point for expanded analyses and estuarine comparison, yet additional work is needed.

Acknowledgments We thank members and volunteers of the Giddings, Guza, and Pawlak labs at UCSD, Whitcraft Lab at CSULB (esp. M. Burdick-Whipp), and the scientists at the Tijuana River National Estuarine Research Reserve for help with data collection. One anonymous reviewer, Dr. Sean Vitousek, and Dr. John Calloway provided valuable feedback which substantially improved this manuscript. Publicly available data are cited within the text, captions and references. Estuary data will be made available through the UCSD library. Any use of trade, product, or firm names in this publication is for descriptive purposes only and does not imply endorsement by the US government.

Funding Information This work was partially funded by California Sea Grant grant no. NA14OAR4170075 with SCCWRP, University of Southern California Sea Grant grant no. 75193327 with Scripps Institution of Oceanography, California Department of Parks and Recreation Division of Boating and Waterways Oceanography Program under contract \#C1670005 with Scripps Institution of Oceanography, California Coastal Conservancy, NOAA National Estuarine Research Reserve System Science Collaborative, Los Peñasquitos Lagoon
Foundation (esp. Mike Hastings), and a Blasker Environment Grant from the San Diego Foundation to Scripps Institution of Oceanography. Funding for Seal Beach, Mugu Lagoon, and Newport Bay data collection was provided by the DOI Southwest Climate Adaptation Science Center and US Geological Survey, Western Ecological Research Center. This work was additionally supported by two traineeships through University of Southern California Sea Grant and the NOAA Ernest F. Hollings Undergraduate Scholarship.

Open Access This article is licensed under a Creative Commons Attribution 4.0 International License, which permits use, sharing, adaptation, distribution and reproduction in any medium or format, as long as you give appropriate credit to the original author(s) and the source, provide a link to the Creative Commons licence, and indicate if changes were made. The images or other third party material in this article are included in the article's Creative Commons licence, unless indicated otherwise in a credit line to the material. If material is not included in the article's Creative Commons licence and your intended use is not permitted by statutory regulation or exceeds the permitted use, you will need to obtain permission directly from the copyright holder. To view a copy of this licence, visit http://creativecommons.org/licenses/by/4.0/.

\section{References}

Adams, Janine. 2014. A review of methods and frameworks used to determine the environmental water requirements of estuaries. Hydrological Sciences Journal 59: 451-465. https://doi.org/10. 1080/02626667.2013.816426.

Barnard, Patrick L., Daniel Hoover, David M. Hubbard, Alex Snyder, Bonnie C. Ludka, Jonathan Allan, George M. Kaminsky, Peter Ruggiero, Timu W. Gallien, Laura Gabel, Diana McCandless, Heather M. Weiner, Nicholas Cohn, Dylan L. Anderson, and Katherine A. Serafin. 2017. Extreme ocean forcing and coastal response due to the 2015-2016 El Niño. Nature Communications 8: 14365. https://doi.org/10.1038/ncomms14365.

Behrens, Dane K., Fabián A. Bombardelli, John L. Largier, Elinor Twohy, (2009) Characterization of time and spatial scales of a migrating rivermouth. Geophysical Research Letters 36 (9).

Behrens, Dane K., Fabián A. Bombardelli, John L. Largier, and Elinor Twohy. 2013. Episodic closure of the tidal inlet at the mouth of the Russian River - A small bar-built estuary in California. Geomorphology 18: 66-80. https://doi.org/10.1016/j.geomorph. 2013.01.017.

Bromirski, Peter D., Reinhard E. Flick, and Daniel R. Cayan. 2003. Storminess variability along the California Coast: 1858-2000. Journal of Climate 16: 982-993.

Cai, W., S. Borlace, M. Lengaigne, P.V. Rensch, M. Collins, G. Vecchi, A. Timmermann, A. Santoso, M.J. McPhaden, L. Wu, M.H. England, G. Wang, E. Guilyardi, and F. Jin. 2014. Increasing frequency of extreme El Niño events due to greenhouse warming. Nature Climate Change 4 (2). https://doi.org/10.1038/nclimate2100.

California Natural Resources Agency. 2010. State of the state's wetlands: 10 years of challenges and progress. Sacremento, CA. Prepared by: Department of Fish and Game, the Southern California Coastal Water Research Project, the San Francisco Estuary Institute, and the State Coastal Conservancy

Cao, Y., Dong, C., Uchiyama, Y., Wang, J., \& Yin, X. ( 2018). Multiplescale variations of wind-generated waves in the Southern California 
Bight. Journal of Geophysical Research: Oceans, 123, 9340- 9356. https://doi.org/10.1029/2018JC014505

Cayan, Daniel R., Peter D. Bromirski, Katharine Hayhoe, Mary Tyree, Michael D. Dettinger, and Reinhard E. Flick. 2008. Climate change projections of sea level extremes along the California coast. Climatic Change 87: 57-73. https://doi.org/10.1007/s10584-007-9376-7.

cdip.usd.edu. 2018. CDIP (The Coastal Data Information Program) Historic Data. https://cdip.ucsd.edu / Buoy ID: 100. Accessed October 112017

Chelton, Dudley B., and Ross E. Davis. 1982. Monthly mean sea level variability along the west coast of North America. Journal of Physical Oceanography 12: 757-784.

Clark, Ross, and Kevin O'Connor. 2019. A systematic survey of bar-built estuaries along the California coast. Estuarine, Coastal and Shelf Science 226: 106285. https://doi.org/10.1016/j.ecss.2019.106285.

Cousins, Mary, Mark T. Stacey, Jeana L. Drake, (2010) Effects of seasonal stratification on turbulent mixing in a hypereutrophic coastal lagoon. Limnology and Oceanography 55 (1):172-186.

Doughty, Cheryl L., Kyle C. Cavanaugh, Richard F. Ambrose, and Eric D. Stein. 2018. Evaluating regional resiliency of coastal wetlands to sea level rise through hypsometry-based modeling. Global Change Biology 25 (1): 78-92. https://doi.org/10.1111/gcb.14429.

Elwany, M., S. Hany, Reinhard E. Flick, and Saima Aijaz. 1998. Opening and closure of a marginal Southern California lagoon inlet. Estuaries 21: 246-254.

Emery, William J., and Richard E. Thomson. 2014. Data analysis methods in physical oceanography. 3rd ed. Waltham, MA: Elsevier.

Enfield, David B., and J.S. Allen. 1980. On the structure and dynamics of monthly mean sea level anomalies along the Pacific Coast of North and South America. Journal of Physical Ocean 10: 557-578.

Erikson L.H., C.A. Hegermiller, P.L. Barnard, P. Ruggiero, M. van Ormondt, (2016) Projected wave conditions in the Eastern North Pacific under the influence of two CMIP5 climate scenarios. Ocean Modeling 96:171-185.

Flick, Reinhard E. 2016. California tides, sea level, and waves - winter 2015-2016. Shore and Beach 84: 25-30.

Friedrichs, Carl T. 2010. Barotropic tides in channelized estuaries. Contemporary issues in estuarine physics. Cambridge: Cambridge University Press. https://doi.org/10.1017/CBO9780511676567.

Gale, Emma, Charitha Pattiaratchi, Roshanka Ranasinghe, (2006) Vertical mixing processes in Intermittently Closed and Open Lakes and Lagoons, and the dissolved oxygen response. Estuarine, Coastal and Shelf Science 69 (1-2):205-216.

Goodman, Arianna, Karen Thorne, Kevin Buffington, Chase Freeman, and Christopher Janousek. 2018. El Niño Increases High-Tide Flooding in Tidal Wetlands Along the U.S. Pacific Coast. Journal of Geophysical Research: Biogeosciences 123. wiley: 3162-3177. https://doi.org/10.1029/2018JG004677.

Graham, Nicholas E., Daniel R. Cayan, Peter D. Bromirski, Reinhard E. Flick, (2013) Multi-model projections of twenty-first century North Pacific winter wave climate under the IPCC A2 scenario. Climate Dynamics 40 (5-6):1335-1360.

Griggs, Gary, Dan Cayan, Claudia Tebaldi, Helen A. Fricker, Joseph Arvai, Robert DeConto, Robert E. Kopp. (California Ocean Protection Council Science Advisory Team Working Group). 2017. Rising seas in California: An update on sea-level rise science. California ocean science trust. https://www.nap.edu/catalog/13389/ sea-level-rise-for-the-coasts-of-california-oregon-and-washington.

Hastings, Mike, and Hany Elwany. 2012. Managing the inlet at Los Peñasquitos Lagoon. Shore and Beach 80: 9-18.

Holleman, Rusty C., and Mark T. Stacey. 2014. Coupling of sea level rise, tidal amplification, and inundation. Journal of Physical Oceanography 44: 1439-1455. https://doi.org/10.1175/JPO-D-130214.1.

Holmquist, James R., Lisamarie Windham-Myers Norman Bliss, Stephen Crooks, James T. Morris, J. Patrick Megonigal, Tiffany Troxler,
Donald Weller, John Callaway, Judith Drexler, Matthew C. Ferner, Meagan E. Gonneea, Kevin D. Kroeger, Lisa Schile-Beers, Isa Woo, Kevin Buffington, Joshua Breithaupt, Brandon M. Boyd, Lauren N. Brown, Nicole Dix, Lyndie Hice, Benjamin P. Horton, Glen M. MacDonald, Ryan P. Moyer, William Reay, Timothy Shaw, Erik Smith, Joseph M. Smoak, Christopher Sommerfield, Karen Thorne, David Velinsk, Elizabeth Watson, Kristin Wilson Grimes, and Mark Woodrey. 2018. Accuracy and precision of tidal wetland soil carbon mapping in the conterminous United States. Scientific Reports 8 (1): 6478-6416. https://doi.org/10.1038/s41598-01826948-7.

Hubbard, David M. 1996. Tidal cycle distortion in Carpinteria salt marsh, California. Bulletin of the Southern California Academy of Sciences 95: 88-98.

Jacobs, David, Eric D. Stein, and Travis Longcore. 2010. Classification of California estuaries based on natural closure patterns: Templates for restoration and management. Southern California Coastal Water Research Project, 619a, 1-50

Janousek, C., K. Buffington, K. Thorne, G. Guntenspergen, J. Takekawa, and B. Dugger. 2016. Potential effects of sea-level rise on plant productivity: Species-specific responses in northeast. Pacific tidal marshes. Marine Ecology Progress Series 548: 111-125. https:// doi.org/10.3354/meps11683.

Largier, J. L., J.H. Slinger, and S. Taljaard. 1992. The stratified hydrodynamics of the Palmiet - A prototypical bar-built estuary. Dynamics and exchanges in estuaries and the coastal zone, D. Prandle (Ed.) https://doi.org/10.1029/CE040p0135 .

Largier, J.L., J.T. Hollibaugh, and S.V. Smith. 1997. Seasonally hypersaline estuaries in Mediterranean-climate regions. Estuarine, Coastal and Shelf Science 45: 789-797. https://doi.org/10.1006/ecss.1997. 0279

Largier, J.L. 2010. Low inflow estuaries: Hypersaline, inverse, and thermal scenarios. Contemporary issues in estuarine physics. Cambridge: Cambridge University Press. https://doi.org/10.1017/ CBO9780511676567.

Largier, J.L., Hearn, C.J. and Chadwick, D.B. 1996. Density Structures in "Low Inflow Estuaries". In Buoyancy Effects on Coastal and Estuarine Dynamics (eds D.G. Aubrey and C. Friedrichs). https:// doi.org/10.1029/CE053p0227

Largier, J.L., K.C. O'Connor, and R.P. Clark. 2019. Considerations for management of the mouth state of California's bar-built estuaries. Final Report. West Coast Region: National Marine Fisheries Service.

Lee, Sang-Ki, Hosmay Lopez, Eui-Seok Chung, Pedro DiNezio, SangWook Yeh, and Andrew T. Wittenberg. 2018. On the fragile relationship between El Niño and California rainfall. Geophysical Research Letters 45: 907-915. https://doi.org/10.1002/ 2017 GL076197.

Los Peñasquitos Lagoon Foundation, ESA, Norby Biological Consulting, KTU+A. 2016. Los Peñasquitos Lagoon Enhancement Plan. http:// www.lospenasquitos.org/wp-content/uploads/2017/05/ LosPenEnhancementPlan-Aug2016.pdf

Ludka, Bonnie C., Robert T. Guza, and William C. O'Reilly. 2018. Nourishment evolution and impacts at four southern California beaches: A sand volume analysis. Coastal Engineering 136: 96 105. https://doi.org/10.1016/j.coastaleng.2018.02.003.

Ludka, Bonnie C., Timu Gallien, Sean C. Crosby, and Robert T. Guza. 2016. Mid-El Niño erosion at nourished and unnourished Southern California beaches. Geophysical Research Letters: 1-7. https://doi. org/10.1002/(ISSN)1944-8007.

Malhadas, Madalena, Paulo Leitão, Adélio Silva, and Ramiro Neves. 2009. Effect of coastal waves on sea level in Óbidos Lagoon, Portugal. Continental Shelf Research 29: 1240-1250. https://doi. org/10.1016/j.csr.2009.02.007.

McSweeney, S.L., D.M. Kennedy, and I.D. Rutherfurd. 2017. A geomorphic classification of intermittently open/closed estuaries (IOCE) 
derived from estuaries in Victoria, Australia. Progress in Physical Geography 41: 421-449. https://doi.org/10.1177/ 0309133317709745.

Morris, B.D., and I.L. Turner. 2010. Morphodynamics of intermittently open-closed coastal lagoon entrances: New insights and a conceptual model. Marine Geology 271 (1-2): 55-66. https://doi.org/10. 1016/j.margeo.2010.01.009.

National Research Council. 2012. Sea-Level Rise for the Coasts of California, Oregon, and Washington: Past, Present, and Future. Washington, DC: The National Academies Press. https://doi.org/ $10.17226 / 13389$.

ncdc.noaa.gov. 2018. National Climatic Data Center. https://www.ncdc. noaa.gov/data-access/ Station ID: USW00023188. Accessed February 2019.

Orescanin, M.A., and J. Scooler. 2018. Observations of episodic breaching and closure at an ephemeral river. Continental Shelf Research 166: 77-82. https://doi.org/10.1016/j.csr.2018.07.003.

O'Reilly, William C., and Robert T. Guza. 1993. A comparison of two spectral wave models in the Southern California Bight. Coastal Engineering 19: 263-282.

O'Reilly, William C., Corey B. Olfe, Julianna Thomas, R.J. Seymour, and Robert T. Guza. 2016. The California coastal wave monitoring and prediction system. Coastal Engineering 116: 118-132. https://doi. org/10.1016/j.coastaleng.2016.06.005.

Phlips, E.J., S. Badylak, and T. Grosskopf. 2002. Factors affecting the abundance of phytoplankton in a restricted subtropical lagoon, the Indian River lagoon, Florida, USA. Estuarine, Coastal and Shelf Science 55: 385-402. https://doi.org/10.1006/ecss.2001.0912.

Pratt, Jamie. 2014. California inlets: A coastal management "No Man's Land," report for the Surfrider Foundation. http://public.surfrider. org/files/ CA Inlet Report 2014.pdf

Ranasinghe, Roshanka, Charitha Pattiaratchi, (1999) Circulation and mixing characteristics of a seasonally open tidal inlet: a field study. Marine and Freshwater Research 50 (4):281.

Ranasinghe, Roshanka, and Charitha Pattiaratchi. 2003. The seasonal closure of tidal inlets: Causes and effects. Coastal Engineering 45: 601-627.

Raposa, Kenneth. 2002. Early responses of fishes and crustaceans to restoration of a tidally restricted New England salt marsh. Restoration Ecology 10: 665-676. https://doi.org/10.1046/j.1526100X.2002.01047.x.

Rich, Andrew, and Edward A. Keller. 2013. A hydrologic and geomorphic model of estuary breaching and closure. Geomorphology 191: 64-74. https://doi.org/10.1016/j.geomorph.2013.03.003.

Roy, P.S., R.J. Williams, A.R. Jones, I. Yassini, P.J. Gibbs, B. Coates, R.J. West, P.R. Scanes, J.P. Hudson, and S. Nichol. 2001. Structure and function of south-east Australian estuaries. Estuarine, Coastal and Shelf Science 53: 351-384. https://doi.org/10.1006/ECSS.2001. 0796.

Saad, Adriana M., Antonio C. Baumord, and Erica P. Caramaschi. 2002. Effects of artificial canal openings on fish community structure of Imboassica coastal lagoon, Rio de Janeiro, Brazil. Journal of Coastal Research SI 36: 634-639.

San Elijo Lagoon Conservancy, AECOM. 2016. Environmental Impact Report/Environmental Impact Statement for the San Elijo Lagoon Restoration Project EIR/EIS. https://thenaturecollective.org/wpcontent/uploads/2019/04/San-Elijo-Lagoon-Restoration-ProjectEIR.pdf

Siler, Nicholas, Yu Kosaka, Shang-Ping Xie, and Xichen Li. 2017. Tropical ocean contribution to California's surprisingly dry El Niño of 2015/2016. Journal of Climate 30: 10067-10079. https:// doi.org/10.1175/JCLI-D-17-0177.1.

Shepard, Christine C., Caitlin M. Crain, and Michael W. Beck. 2011. The protective role of coastal marshes: A systematic review and metaanalysis. PLoS One 6 (11): e27374-e27311. https://doi.org/10.1371/ journal.pone.0027374.
Southern California Wetlands Recovery Project. 2018. Wetlands on the edge: The future of Southern California's wetlands: Regional Strategy 2018. Prepared by the California state coastal Conservancy, Oakland, CA. https://scwrp.org/wp-content/uploads/ 2018/10/WRP-Regional-Strategy-2018-100518 lowRes.pdf

Sweet, William V., and Joseph Park. 2014. From the extreme to the mean: Acceleration and tipping points of coastal inundation from sea level rise. Earths Future 2: 1-22. https://doi.org/10.1002/28ISSN/923284277.

Sweet, William V, R Horton, R E Kopp, A N LeGrande, and A Romanou. 2017: Sea level rise. In: Climate Science Special Report: Fourth National Climate Assessment, Volume I /Wuebbles, D.J., D.W. Fahey, K.A. Hibbard, D.J. Dokken, B.C. Stewart, and T.K. Maycock (eds.)]. U.S. Global Change Research Program, Washington, DC, USA, pp. 333-363. https://doi.org/10. 7930/J0VM49F2.

Tagliapietra, D., M. Sigovini, and A.V. Ghirardini. 2009. A review of terms and definitions to categorise estuaries, lagoons and associated environments. Marine and Freshwater Research 60: 497-509.

Takekawa, John Y., Isa Woo, Rachel Gardiner, Michael Casazza, Joshua T. Ackerman, Nadav Nur, Leonard Liu, and Hildie Spautz. 2011. Avian communities in tidal salt marshes of San Francisco Bay: A review of functional groups by foraging guild and habitat association. San Francisco Estuary and Watershed Science 9: 1-25.

Tebaldi, Claudia, Bejamin H. Strauss, and Chris E. Zervas. 2012. Modeling sea-level rise impacts on storm surges along US coasts. Environmental Research Letters 7: 14032. https://doi.org/10.1088/ 1748-9326/7/1/014032.

Teske, Peter R., and Tris Wooldridge. 2001. A comparison of the macrobenthic faunas of permanently open and temporarily open/ closed South African estuaries. Hydrobiologia 464: 227-243. https://doi.org/10.1023/A:1013995302300.

Tidesandcurrents.noaa.gov. 2018. NOAA Products Tides and Water Levels, https://tidesandcurrents.noaa.gov/stations.html?type $=$ Water+Levels, Station IDs: 9410230, 9410660, 9410170, and 9410840. Accessed February 2019.

Thomson, Richard E., and William J. Emery. 2014. Data analysis methods in physical oceanography. Third ed. Waltham, MA: Elsevier B.V..

Thorne, Karen M., Glen M. MacDonald, Rich F. Ambrose, Kevin J. Buffington, Chase M. Freeman, Christopher N. Janousek, Lauren N. Brown, James R. Holmquist, Glenn R. Guntenspergen, Katherine W. Powelson, Patrick L. Barnard, and John Y. Takekawa. 2016. Effects of climate change on tidal marshes along a latitudinal gradient in California. U.S. Geological Survey Open-File Report 20161125: 1-87. https://doi.org/10.3133/ofr20161125.

Thorne, Karen M., Deborah L. Elliott-Fisk, Chase M. Freeman, Thuy-Vy D. Bui, Katherine W. Powelson, Christopher N. Janousek, Kevin J. Buffington, and John Y. Takekawa. 2017. Are coastal managers ready for climate change? A case study from estuaries along the Pacific coast of the United States. Ocean \& Coastal Management 143: 38-50. https://doi.org/10.1016/j.ocecoaman.2017.02.010.

Thorne, Karen, Glen MacDonald, Glenn Guntenspergen, Richard Ambrose, Kevin Buffington, Bruce Dugger, Chase Freeman, Christopher Janousek, Lauren Brown, Jordan Rosencranz, James Holmquist, John Smol, Kathryn Hargan, and John Takekawa. 2018. U.S. Pacific coastal wetland resilience and vulnerability to sea-level rise. Science Advances 4: eaao327. https://doi.org/10. 1126/sciadv.aao3270.

van Belzen, Jim, Johan van de Koppel, Matthew Kirwan, Daphne van der Wal, Peter Herman, Vasilis Dakos, Sonia Kéfi, Marten Scheffer, Glenn Guntenspergen, and Tjeerd Bouma. 2017. Vegetation recovery in tidal marshes reveals critical slowing down under increased inundation. Nature Communications 8: 15811. https://doi.org/10. 1038/ncomms15811. 
Walters, Roy A., and Cynthia Heston. 1982. Notes and correspondence: Removing tidal-period variations from time-series data using lowpas digital filters. Journal of Physical Oceanography 12: 112-115. https://doi.org/10.1175/1520-0485.

Waterdata.usgs.gov. 2018. https://waterdata.usgs.gov/ca/nwis/uv/ National Water Information System: USGS Stream Gauge: 11023340. Accessed February 2019.

Whitfield, A.K. 1992. The characterization of southern African estuarine systems. Southern African Journal of Aquatic Sciences 26: 31-38.

Williams, Megan E., and Mark T. Stacey. 2016. Tidally discontinuous ocean forcing in bar-built estuaries: The interaction of tides, infragravity motions, and frictional control. Journal of Geophysical Research: Oceans 121: 571-585. https://doi.org/10. 1002/2015JC011166.
Young, Adam P., Reinhard E. Flick, Timu W. Gallien, Sarah N. Giddings, Robert T. Guza, Madeleine Harvey, Luc Lenain, Bonnie C. Ludka, W. Kendall Melville, and William C. O'Reilly. 2018. Southern California coastal response to the 2015-2016 El Niño. Journal of Geophysical Research: Earth Surface 123: 3069-3083. https://doi. org/10.1029/2018JF004771.

Zedler, Joy B. 2010. How frequent storms affect wetland vegetation: A preview of climate-change impacts. Frontiers in Ecology and the Environment 8: 540-547. https://doi.org/10.1890/090109.

Zedler, Joy B., and Suzanne Kercher. 2005. Wetland resources: Status, trends, ecosystem services, and restorability. Annual Review of Environment and Resources 30: 39-74. https://doi.org/10.1146/ annurev.energy.30.050504.144248. 